Desenhos, linhas, entrelinhas'

\section{Drawings, lines and lines}

Gláucia Affonso é pedagoga formada pela Pontifícia Universidade Católica de São Paulo (PUC-SP) com especialização em Educação Inclusiva pelo Instituto Superior de Educação Vera Cruz (ISEVEC). Atua como orientadora educacional na Escola Vera Cruz e como professora universitária no Instituto Singularidades.

Contato: glau.affonso@hotmail.com

Claudia Lopes Silva é professora universitária do ISEVEC, psicóloga escolar na Secretaria de Educação de São Bernardo do Campo e doutoranda em Educação pela Faculdade de Educação da Universidade de São Paulo (FEUSP).

Contato: psi.clau@gmail.com

\section{Resumo}

Este artigo conta a história de Caio, um aluno com espectro autista, matriculado em escola comum, descrevendo seu percurso dos cinco aos oito anos. 0 objetivo é compartilhar as dúvidas, os acertos e as flexibilizações que foram sendo realizados para que Caio usufruísse do dia a dia escolar, tendo sua singularidade respeitada, criando a possibilidade de potencializar experiências semelhantes.

Palavras chave: atendimento à diversidade escolar; inclusão; autismo.

\section{Abstract}

This article tells the story of Caio, a student with autism enrolled in regular school and describes his journey from five to eight years. The goal is to share the doubts, the achievements and the adaptations that were made so that Caio would enjoy the school's day-to-day activities, having
1. 0 artigo foi escrito a partir do trabalho de conclusão de curso da especialização em Educação Inclusiva do ISEVEC, relatando a experiência da primeira autora (Gláucia Affonso), sob orientação da segunda autora (Claudia Lopes Silva). Manteve-se a escrita em primeira pessoa, como no trabalho original. 
his uniqueness respected and creating the possibility of the amplification of similar experiences.

Keywords: compliance with school diversity; inclusion; autism.

Desde a década de 1990, cresce um movimento mundial que visa à inclusão de TODAS as pessoas na escola comum; a inclusão vem ganhando espaço em nossa sociedade, as leis estão cada vez mais claras, mas ainda há muitas barreiras a serem transpostas.

A possibilidade de conhecer e incorporar o diferente na sociedade começa na escola. A diferença desvelada torna-se relação entre humanos. Saad (2003, p. 245) pontua que "[...] ser diferente não significa ser desigual, uma vez que somos todos igualmente diferentes". Mantoan (2009) afirma que "[...] a diferença é o conceito que se impõe para que possamos defender a tese de uma escola para todos". A convivência é a melhor forma de conhecermos alguém diferente de nós; todos ganham com o convívio com as diferenças. A história de Caio corrobora com estas ideias, como se poderá ver nas linhas que se seguem.

Meu encontro com Caio, como orientadora educacional do Jardim II (grupo de crianças com faixa etária entre cinco e seis anos), em uma escola particular de educação básica em São Paulo (SP), fez com que minhas crenças a respeito do atendimento à diversidade em escolas comuns fossem levadas a um patamar diferente, tornando-se um desafio de um porte que até então eu não havia enfrentado em minha prática educativa. As dificuldades que ele apresentava em virtude de seu espectro autista, e os desafios em fazê-lo pertencer à escola e participar das atividades propostas mobilizaram toda a equipe. Vivemos momentos de recuo, aparentes retrocessos, frustrações, sensação de que não daríamos conta. Aprendi que o tempo é relativo e em um tempo diferente, não linear, as possibilidades e conquistas foram aparecendo.

Sabia que seria orientadora educacional do grupo de Caio, que ele tinha um quadro de autismo e que gostava de desenhar. Porém, o que exatamente constitui um diagnóstico de autismo? Como trabalhar com uma criança que, no meu imaginário, não interagia? Como faríamos para atendê-lo? Como seria seu convívio com os demais? Conseguiria alfabetizar-se? Como faríamos para que avançasse nesse sentido? Poucas certezas e muitas, muitas perguntas, era isso que eu tinha em mãos. 
No início do ano, conversei com sua orientadora anterior e eu e a equipe nos preparamos para o novo desafio, já sabendo de sua história inicial. Na escola em que eu trabalhava, a orientadora acompanhava o grupo de alunos; meu ciclo com aquela turma seria de três anos.

Caio cursou o Maternal duas vezes em razão de sua dificuldade em estabelecer contato, e a escola manteve as mesmas professora e professora auxiliar em sua sala naquela ocasião. Mais adiante, optou-se por manter cada professora por dois anos na sala de Caio, pois a equipe considerou que manter os vínculos que se formavam era importante para ele. Assim, Caio teve também uma mesma professora, Ana, durante o Jardim I e o Jardim II e outra, Marina, durante o Pré e a $1^{\mathrm{a}}$ série.

Caio apresentava uma habilidade impressionante para desenhar, mas pouco se comunicava verbalmente. Desde os dois ou três anos, em seus desenhos, apareciam personagens claramente caracterizados. Nessa fase, as crianças geralmente fazem rabiscos ou garatujas sem formas definidas ou começam a formar círculos e a dar nomes aos seus desenhos. Segundo Sacks (2009, p. 193), "talentos singulares, normalmente surgindo na mais tenra idade e se desenvolvendo numa velocidade surpreendente, aparecem em cerca de $10 \%$ dos autistas". Os super-heróis eram o tema mais constante em seus desenhos; apareciam com seus detalhes marcantes e em movimento. A Figura 1 evidencia a forma como desenhava quando o conheci. Ao observar com atenção o fundo e as bordas da figura, podemos vislumbrar muitos personagens como se estivessem em ação, talvez lutando.

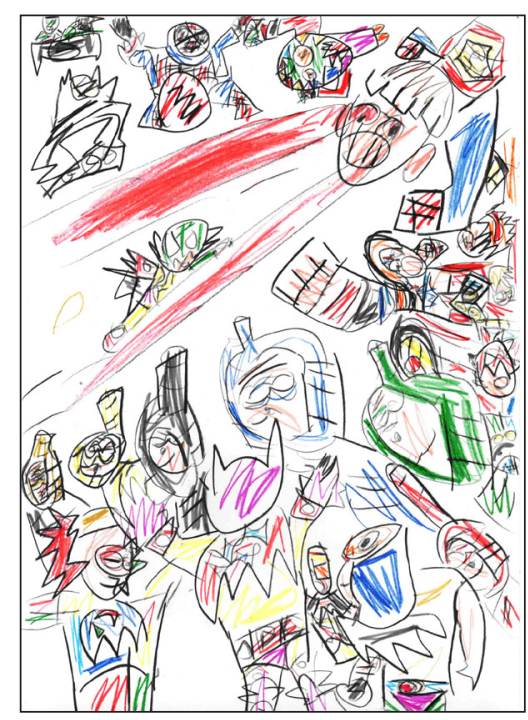

Figura 1 - Heróis (idade: cerca de quatro anos) 
Iniciamos o Jardim II, e eu passei a ser orientadora daquela turma. Por um bom tempo, Caio parecia não perceber minha existência. Era como se seu olhar me atravessasse, como se eu fosse transparente. Com Ana, sua professora pelo segundo ano consecutivo, tinha uma relação de proximidade, atendia a alguns de seus chamados e correspondia quando ela lhe pedia um beijo ou um abraço. Essas atitudes já desconstruíam em mim a ideia estereotipada que tinha a respeito de pessoas com autismo, como sendo incapazes de formar vínculos. Klin, Rosário e Mercadante $(2009$, p. 19) afirmam que "[...] existe um mito acerca da falta de afetividade da criança com autismo, o que não é corroborado pelos estudos. [...] não existiria um prejuízo na afetividade, mas sim, dos sistemas que controlam o processo dessas manifestações [...]".

Ao longo do primeiro semestre do Jardim II, Caio praticamente não falou com efeito comunicativo, embora respondesse a alguns de nossos contatos repetindo palavras ao final de nossas falas, ampliando seu vocabulário dia a dia. Nessa época era acompanhado por uma fonoaudióloga e também por uma psicanalista.

Vê-lo desenhar é até hoje uma das cenas mais bonitas que já presenciei. Gostava de desenhar com canetinhas hidrográficas do tipo Pilot, escolhia quatro cores, tirava as tampas, abria a mão esquerda e colocava as canetas encaixadas nos espaços entre os dedos, formando uma "paleta". Uma quinta caneta ficava em sua mão direita e, com ela, começava seu desenho. De aparentes rabiscos iam surgindo os personagens; Caio não começava a desenhar fazendo o rosto, dois olhos, a boca, cabelo. Às vezes, começava por um traço que depois se revelava o cinto do herói, uma sobrancelha, o tórax... Os riscos iam se sobrepondo conforme trocava de caneta, retirando alguma da "paleta" e encaixando entre os dedos a que não usava. De repente, era possível visualizar o personagem, em geral em movimento, em perspectivas diferentes, um personagem na frente e outro atrás, um superhomem voando, o rosto raivoso ou satisfeito... Além de o resultado ser figurativo e detalhado, chamava a atenção sua capacidade de desenhar com perspectiva e indicação de movimento, como se pode observar nas Figuras 2 e 3. 


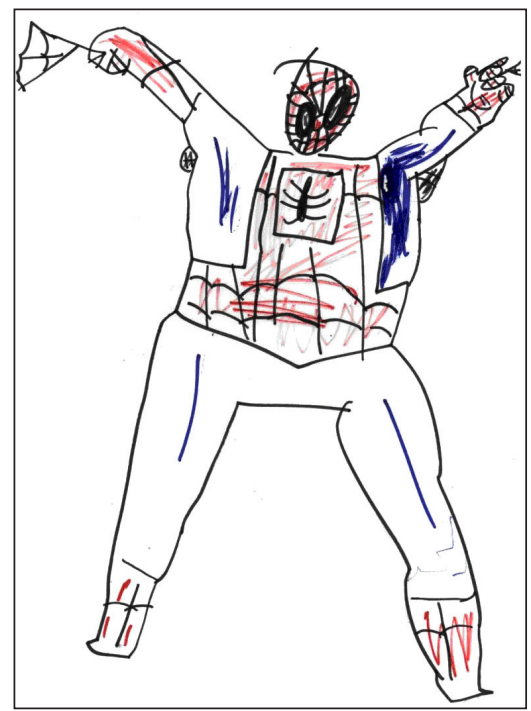

Figura 2 - Homem Aranha (idade: seis anos)

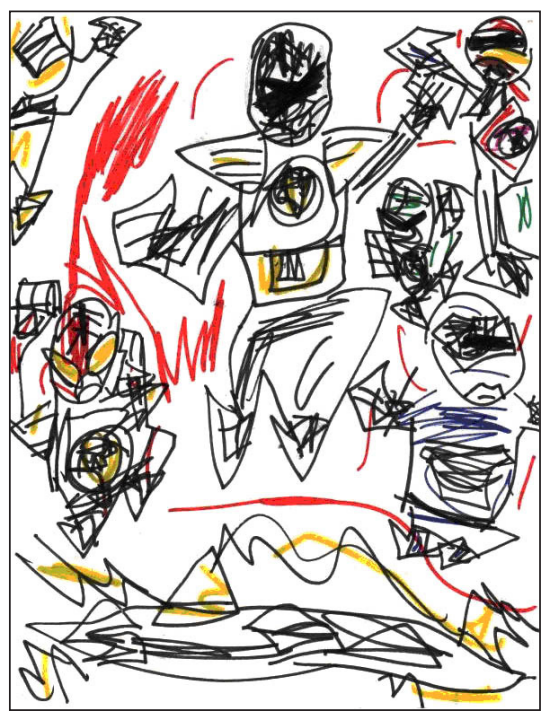

Figura 3 - Power Rangers (idade: seis anos e cinco meses)

Sacks (2009, p. 206-207), ao descrever o desenho de Stephen, também autista, comenta aspectos que se assemelham aos que eu via enquanto Caio produzia seus desenhos: "[...] Stephen não fez nenhum esboço ou delineamento, apenas começou num dos cantos do papel (tive a sensação de que podia ter começado em qualquer lugar) [...] 0 desenho de Stephen era exato em certos aspectos, mas tomava muitas liberdades em outros [...]".

Era difícil para Caio permanecer na sala durante todo o período escolar e, quando uma de nós o chamava, em geral, não atendia de imediato. Gostava especialmente de correr em círculos, segurando com uma das mãos no gira-gira do parque e, quando o chamávamos, corria com mais rapidez ainda. Grandin e Scariano (2010, p. 118-119) apontam que "há estudos que mostram que as crianças autistas muitas vezes têm primeiro medo de movimentos rápidos e depois ficam fixadas neles. [...] as crianças autistas gostam de estímulos intensos [...]".

0 corre-corre de Caio quando eu o chamava acabou tornandose um "pega-pega"; ele esperava o chamado ou algum movimento meu em sua direção, olhava para mim e driblava-me em alegres correrias pelo pátio. Quanto mais eu o chamava mais ele fugia e minha missão de levá-lo para a classe naufragava.

Num dos primeiros encontros que tive com a psicanalista de Caio, depois de lhe relatar tentativas frustradas de contato, ela me disse algo que passou a ser a grande diretriz para mim em sua conduta: "é ele quem tem o passaporte e a chave de entrada. Nós é que temos que ir em sua direção e ele nos autoriza ou não a 
entrar". Como era difícil pensar e agir nessa direção para nós! Fazer contato sem esperar um retorno, falar e não esperar resposta oral, abrir mão de resultados visíveis...

Um dia, ao chamá-lo de volta para a classe após o recreio, decidi tentar uma abordagem diferente, pensando na conversa com a psicanalista. Brinquei por um tempo e depois lhe disse que a brincadeira acabara. Fui até ele, peguei em sua mão e lhe disse "vamos para a sala" e, surpreendentemente, ele veio! Foi tão simples e eu nunca tentara esse caminho antes! A partir de então, quando o chamávamos de volta para sala, pegávamos em sua mão e ele ia para a classe, simples assim!

Era muito difícil sabermos o que de fato Caio sabia a respeito de letras e números, pois sua explicitação era muito rara. Aprendera a escrever seu nome valendo-se do modelo que lhe oferecíamos para copiar e depois prescindindo dele. Um detalhe na escrita de seu nome chamava muito minha atenção e a de Ana, o fato de ele escrever "Caio", mas, ao final, colocar um C ao contrário, como se fechasse um parêntesis em si mesmo (Figura 4):

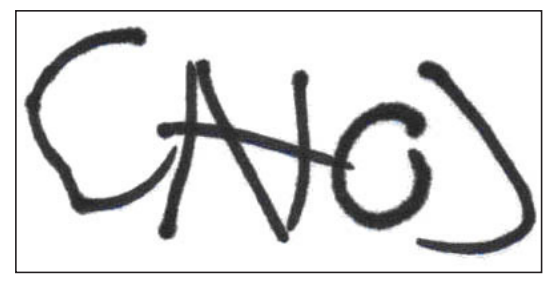

Figura 4 - Exemplo da assinatura de Caio

Em busca de entender Caio e de encontrar possibilidades de trabalho com ele, eu havia lido alguns textos sobre autismo e o registro de outro aluno com o mesmo quadro que passara pela escola. Uma amiga me indicou o livro de Oliver Sacks, Um antropólogo em Marte, e foi esse livro, em especial seu capítulo homônimo, que me ajudou a entender o autismo. No texto, Sacks relata seu encontro com Temple Grandin, uma autista com grandes habilidades que, à época do contato com Sacks, já era professoraassistente no departamento de Ciências Animais na Colorado State University e já havia publicado uma autobiografia em que relata sua infância e adolescência como autista. 0 texto trouxe para mim a visão de um ser humano que se desenvolve com características próprias e não com aquelas da síndrome. A incerteza a respeito de Caio permanecia, mas passei a entender que na vida e, especialmente, na educação de seres humanos a incerteza está sempre presente. 
Tínhamos dúvidas do que seria melhor para Caio, seguir em frente com o grupo ou ficar mais um ano no Jardim II. Pensando na ideia de que seria ele quem abriria ou fecharia a porta, passei a buscar indícios para descobrir qual caminho Caio escolheria. Percebi que, em alguns momentos, ele mostrava saberes elaborados e pertinentes ao desenvolvimento de sua faixa etária, em outros momentos, entretanto, seu desenvolvimento estava aquém, ou ainda, além do que se esperava de crianças aos seis anos de idade. Com isso, pedi a Ana que registrasse cada aquisição ou competência de Caio que lhe fosse perceptível, mesmo que realizada apenas uma vez. Nossa dificuldade em afirmar o que ele sabia ou não, residia no fato de ele não manter suas conquistas aparentes e constantes aos nossos olhos. Minha ideia era organizar o que sabíamos sobre o que ele já dominava ou que sabia fazer. Eu acreditava que, se ele havia feito algo uma vez, era porque sabia fazê-lo e, se não tornava constante e visível a aquisição, era porque não queria.

Partimos para a ação, construindo um registro dos saberes de Caio. Ana registrava tudo o que ela e Cecília observavam. A lista foi se constituindo de itens como: abre o iogurte e toma sem derrubar; olha nos olhos quando pedimos; escreve seu nome; desenha figurativamente, com perspectiva e movimento; abraça e beija a professora a pedido dela e, às vezes, toma a iniciativa; estabeleceu um vínculo próximo com a professora de educação física e a auxiliar de classe; experimenta hipóteses de escrita com imitações de letra cursiva e, às vezes, aparecem letras e números fidedignos; responde a algumas perguntas com palavras ou frases curtas, em geral, repetindo o que dissemos; conta os colegas seguindo razoavelmente a sequência numérica; participa de parte da aula de educação física etc. Todos esses saberes existiam, embora pudessem ter sido observados apenas uma vez.

Na volta das férias de julho, um fato muito importante se somou à lista: Caio falou em resposta à fala de uma colega, narrando uma vivência sua nas férias e comunicando uma ideia própria. Estávamos sentados em roda, no chão, iniciando uma conversa a respeito de assuntos que os alunos quisessem compartilhar. Uma das meninas da classe contou que havia andado a cavalo nas férias. Depois de um breve silêncio, sem anunciar o que ocorreria, Caio sorriu e disse: "Andou a cavalo foi? Caio também andou a cavalo... no Pantanal". Foi como se uma clareira se abrisse, Ana, Cecília e eu mal respirávamos de emoção. Ana respondeu que aquilo devia ter sido uma delícia e perguntou o que mais ele viu no Pantanal. Caio falou que viu jacaré, arara e tuiuiú. Em seguida o 
silêncio se fez novamente, até outra criança ocupar o espaço. Caio "fechou a porta" e só voltou a falar com intenção comunicativa no passeio que fizemos no final do ano.

Mais um grande desafio, passear com os alunos por um dia inteiro numa fazenda. Combinamos que, nos momentos em que ele não permanecesse com o grupo, eu estaria por perto dele. Tínhamos tantos medos... e se ele fugisse correndo, se se escondesse e não o encontrássemos, e se não quisesse comer? Nesse passeio descobrimos mais uma grande sabedoria de Caio, ele fugia quando estava na escola, lugar conhecido e seguro para ele, em lugares estranhos, como a fazendinha, visitas a museus ou viagens, não arriscava e estava sempre perto de uma de nós. Quando nos sentamos ao redor do lago, eu fiquei ao seu lado de novo e ele voltou a conversar, perguntando-me porque o peixe estava na água e chamando-o de bonitinho. Definitivamente a chave do contato estava com ele, mas a condição estava criada.

Decidimos que Caio seria promovido ao Pré, de um lado porque em nossa lista constavam saberes que lhe serviriam de base, se assim o quisesse, mas, sobretudo, pela capacidade de interagir e reagir à ação do outro que revelou no segundo semestre, ao estabelecer diálogos a partir da situação e da fala de outras pessoas, o que nos parecia seu grande crescimento.

No final do ano, como finalização de um projeto sobre lendas brasileiras, Ana propôs aos alunos que fizessem um painel de desenhos. Como Caio havia se interessado pela Mula sem cabeça, Ana sugeriu que ele a desenhasse. No entanto, ele ficou muito agitado e fez somente rabiscos raivosos. Num outro dia, Ana foi com ele até minha sala solicitando que fizesse o desenho comigo. Caio pegava uma folha atrás da outra, riscava-as de forma absolutamente distante à sua capacidade de desenhar e me entregava. Depois de bastante tempo nessa "luta", desenhou um arco-íris. Ainda não era a Mula sem cabeça mas, naquele momento, julguei que tínhamos realizado um avanço, depois de tantos rabiscos. Entregamos o desenho para Ana que o colocou no mural com parte do cenário dos personagens e assim terminamos o Jardim II.

\section{O Pré e o bumba meu boi}

No primeiro dia de aula, Marina, professora do Pré, me avisou que Caio fizera um desenho para mim. Passei em sua sala e ele me entregou. Era um desenho de... uma mula sem cabeça soltando 
fogo pelas ventas! Aquela mula que ele se recusara a fazer no ano anterior! Aprendi, mais uma vez, a respeitar o tempo e a encará-lo com relatividade. Recebi o presente, dei um abraço em Caio e lhe disse que ele estava com cara de aluno do Pré. Entendi que ele me entregara seu passaporte de entrada no Pré.

Conversei bastante com Marina e Cristina (auxiliar da classe) contando-Ihes de características do grupo e de Caio dentro do grupo. Combinamos que, se Caio precisasse dar suas voltas, teria como limite o portão que separava os pátios, sem passar para o pátio do Jardim II, onde ficava o gira-gira, sem nossa companhia. Como já esperávamos, Caio tentou algumas vezes passar para o outro pátio, mas o portão e os professores de Educação Física, que davam aula na quadra, se constituíram em limites concretos que, pouco a pouco, passou a respeitar. Gostava de sentar-se no banco e observar a aula de Educação Física e, com o tempo, passou a participar de aulas dadas para outras turmas da escola. Eu e Marina acabamos intitulando esses momentos como "as aulas eletivas de Caio".

Os desenhos tornavam-se cada dia mais ricos (Figura 5) e, além disso, aceitava fazer tentativas de escrita e algumas das atividades gráficas relativas à alfabetização e à matemática.

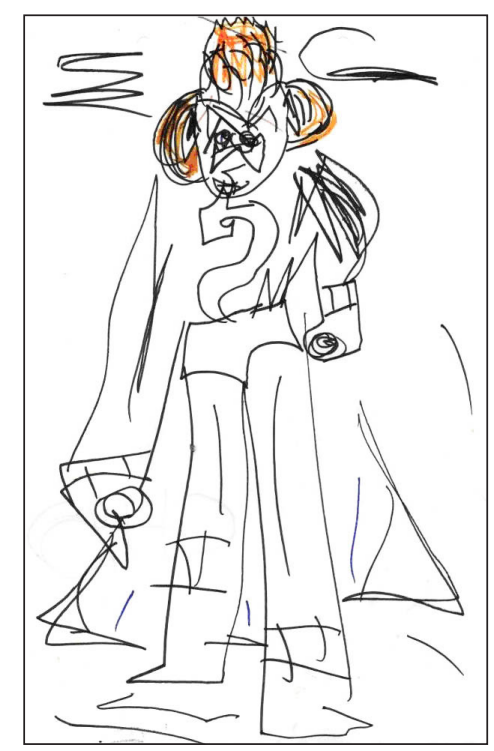

Figura 5 - Herói (idade: seis anos e seis meses)

$\mathrm{Na}$ hora do recreio, Caio corria junto com alguns colegas, ia ao gira-gira, ao trepa-trepa ou observava o movimento com os olhos vívidos de quem está imaginando uma história toda sua. Apesar de estabelecer maior contato com os colegas, os momentos de isolamento ainda eram os mais frequentes.

Conversei com os pais e indiquei um trabalho psicopedagógico 
de forma que pudéssemos ter maior apoio na alfabetização e nas formalizações escolares. Nessa época, ele deixara o trabalho fonoaudiológico e permanecia em análise. Os pais buscaram o atendimento, no entanto, a psicopedagoga achou que Caio ainda estava muito fechado para que um trabalho dessa ordem pudesse surtir efeito. No contato que tivemos na época, ela me disse que era muito importante que "olhássemos para a pessoa na síndrome e não para a síndrome na pessoa", ideia que passou a ecoar em mim e tornou-se mais um norte no trabalho com Caio e com as diferenças.

Em maio, aproximadamente, Caio passou por um período de forte angústia. Era difícil despedir-se de seus pais e ficar na escola. Depois que ficava, chorava e gritava. Procurávamos acolhê-lo, mas não sabíamos o que fazer. Ele dizia "quero desenhar!", e Marina oferecia o material dizendo-lhe "desenha!", mas imediatamente ele gritava: "não quero desenhar!", e Marina lhe dizia que não desenhasse, no que ele voltava a dizer que queria desenhar. 0 mesmo ocorria com o lanche ou com qualquer coisa que implicasse numa decisão sua. Foram mais ou menos quinze dias ininterruptos de "quero / não quero". Quando este movimento cessou, Caio começou a bater em alguns colegas, sem motivo aparente. Eu entendia isso como um avanço, ele saiu de sua crise isolada e queria fazer contato, mas machucava. Escolhia principalmente as meninas, as que mais cuidavam dele e elas, sem entender sua atitude, choravam magoadas... Procurávamos mostrar o efeito que causava nas colegas, elas Ihe diziam que estavam chateadas, mas nada mudava. Após alguns episódios em que Caio bateu nos colegas, Cristina, auxiliar da classe, veio chamar-me após o recreio. Caio batera de novo. Cheguei decidida, peguei-o pela mão e lhe disse: "Você não vai ficar mais na sala, não pode bater". Ficamos um tempo em minha sala e, depois que ele se acalmou, levei-o de volta à classe tornando a dizer que não podia bater nas pessoas.

0 que ocorreu dali em diante foi a abertura de um caminho que eu nem imaginava. Caio passou a ir até minha sala vez por outra, desenhava ou fazia alguma atividade designada por Marina e, depois, descíamos juntos para sua sala. Nesse período, estávamos ensaiando o Bumba meu boi com todo o Pré, que seria apresentado na festa junina da escola. Nos ensaios que tivemos, ele se limitava a correr pelo pátio e, vez por outra, dava um soco nas costas de alguém. Queríamos muito que participasse, por outro lado, a equipe estava apreensiva devido ao momento agressivo pelo qual passava - como controlar isso numa apresentação com setenta crianças? Como dar-lhe um lugar que ele pudesse de fato ocupar produtivamente? 
A resposta veio de suas "aulas eletivas". Incentivado por sua professora de Educação Física do ano anterior, Caio vinha utilizando uma "caixa do divino", uma pequena alfaia, marcando ritmos com ela. Combinei com seus professores que tentaríamos colocá-lo junto com os músicos no ensaio e na apresentação. Eu participava do coro de professores e estaria por perto para cuidar dele. Expliquei-Ihe que essa seria sua função e ele participou de uns dois ensaios já como músico. Às vésperas da apresentação, o professor de Educação Física, encarregado dos ensaios, disse que queria que ele aparecesse em meio à dança. Criou um desfile final em que todos os participantes, brincantes, músicos, cantores passeariam pelo pátio. E assim foi. No dia da apresentação, fiquei ao seu lado, cantando e dizendo quando parar ou segurando a mão de Caio quando não era hora de tocar a caixa. Ele batia com força, e estava feliz. Mais adiante estava sua mãe que sorria e chorava ao mesmo tempo. Foi o espaço aberto por cada um dos membros da equipe que possibilitou a participação de Caio nesse momento escolar grupal. Sozinhos, nenhum de nós teria conseguido.

No segundo semestre, meus encontros com Caio mudaram de figura, configurando-se como um atendimento pedagógico. Quando eu chegava à escola após o almoço, recebia o recado na secretaria de que ele estava me procurando. Conversei com minha coordenadora e resolvi mudar minha rotina, deixando algum horário do dia livre para atendê-lo. Combinei com a professora Marina que, quando ele viesse, trouxesse algum trabalho escolar para fazer comigo e assim se fez. Na maioria das vezes, ele vinha direto à minha sala após deixar seus pertences na sala de aula com Marina. Quando ocorria de não me encontrar, deixava seus recados na secretaria ou com alguma de minhas colegas orientadoras. A ideia de fazê-lo ir à secretaria quando não me encontrava havia sido de Marina para ensinar-Ihe caminhos de acesso que poderia usar, quando necessitasse encontrar alguém na escola.

Além de fazer os trabalhos que Marina encaminhava, eu fazia com ele atividades que envolviam contagem, escrita e reconhecimento de números, ditados de palavras e escrita de textos escritos em sua hipótese ou ditados por ele para mim. Ele chegava à minha sala muito disposto dizendo, "Oi Gáu, vamos trabalhar?", ou então, "0 que vamos fazer? e agora?". Em alguns dias, não queria fazer o que Marina separara, então começávamos o encontro por outra atividade ou o deixava desenhar. Foi interessante perceber em mim uma forma bem ampla de lidar com o planejamento, fruto de minha relação com Caio. Embora houvesse um planejamento prévio, ele era um leque de opções e, de acordo com nossas negociações, eu seguia por um ou outro 
caminho. Um desses caminhos levou ao texto abaixo, um texto em forma de carta, ditado por ele a partir de perguntas minhas e digitado por mim.

\author{
Oi amigos, oi Marina, \\ Eu vou contar para os amigos que eu fui para Guaicá. Guaicá tem praia, eu \\ nadei no mar. Eu fui para Guaicá com o papai, a mamãe, o João, o Paulo e \\ a Wal que foi junto. \\ Eu vou contar pra Marina que eu fui para Guaicá. Eu brinquei na areia, eu \\ corri na areia. \\ Tinha caverna e bichos. A caverna era do morcego, eu vi morcego na \\ caverna. Eu fui para o Pantanal. Tinha anta tomando banho, eu tinha \\ jacaré tomando banho. Eu vi jaguatirica, louro, arara. E tinha tucano, eu \\ tinha morcego. Eu vi lago azul na caverna! Eu fui para o Pantanal eu tinha \\ caverna do Batman... Eu tinha caverna bem bonita...tinha o Batman e o \\ Robin na caverna. A vovó ela ficou num hotel. \\ Eu coloquei máscara para procurar o Nemo, eu mergulhei de máscara \\ para procurar o Nemo. Eu vi peixinhos nadando. Eu tinha a cachoeira. Eu \\ coloquei a roupa e a máscara para procurar o Nemo na água! Eu desci no \\ rio de boia, na cachoeira do rio de boia. Eu fui viajar de avião bem bonito!
}

Nos nossos encontros, usamos também o computador, ora para digitar, ora para aprender a ligá-lo e desligá-lo, ora para usar CD-ROMs educativos. Com eles, foi possível ensinar Caio a utilizar bem o computador, sendo que o CD-ROM preferido era de desenhos com o tema do Batman. Também o ensinei a fazer buscas na internet, soletrando a palavra para que ele pudesse digitar e encontrar o que desejava (em geral assuntos ligados aos heróis) e, depois, ler para ele as informações. A leitura e a escrita foram aparecendo como recursos para tudo o que fazíamos, sem necessidade de artifícios, pois o mundo assim se apresenta; bastou apresentá-lo por inteiro a Caio.

Caio ainda saia para suas "aulas eletivas" de Educação Física, mas permanecia por mais tempo em sua sala, após o trabalho diário comigo. As crises de angústia praticamente haviam sumido, embora ainda batesse em colegas vez por outra. Necessitava de Marina ao seu lado para corresponder ao que era pedido nas aulas de Português e Matemática, mas depois dessa atenção inicial, seus saberes eram perceptíveis.

Com relação à alfabetização, seguimos com Caio um caminho igual ao das demais crianças da escola, baseando-nos nas pesquisas de Emília Ferreiro. Em pouco tempo, foi necessário buscar caminhos diferentes, respeitando o seu tempo - enquanto a grande maioria das crianças terminou o Pré alfabetizada, Caio só 
finalizou sua alfabetização quase um ano depois, além de ser um ano mais velho que as demais crianças do grupo.

Com relação às outras crianças, Caio tinha um grupo de mais ou menos seis colegas, que o conhecia desde o maternal, entendendo-o bem. Brincavam de correrias ao seu lado, admiravam seus desenhos e cobravam dele uma atitude mais adequada quando achavam necessário. Muitas vezes, Caio atendia mais rapidamente a eles do que aos adultos. A classe aprendeu a conviver com seu jeito diferente e, até mesmo, a manter a atenção em momentos em que Marina contava uma história enquanto ele gritava, por exemplo. 0 principal, nessa relação, foi o respeito, a tolerância e a generosidade que se estabeleceu entre eles e Caio. Do meu ponto de vista, essas atitudes se desenvolveram devido à convivência entre diferentes, possibilitada pela educação inclusiva.

Após quase dois anos, num tempo não linear, eu já enxergava um caminho percorrido: avanços no desenvolvimento de Caio, meu crescimento como educadora, uma equipe cada vez mais competente e a reafirmação de um ambiente escolar onde se respeitava as diferenças e o percurso de cada um. Os desenhos de Caio continuavam impressionantes, como se vê na Figura 6, feita com caneta esferográfica.

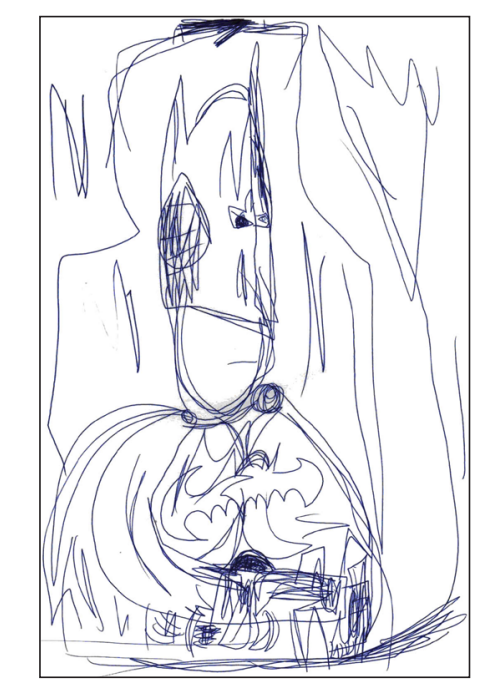

Figura 6 - Batman (idade: sete anos e seis meses)

Desenhava com muita rapidez e não mostrava apego ao que fazia. Dependendo do dia, amassava e jogava fora um bom desenho ou deixava um monte deles sobre minha mesa e ia embora.

No segundo semestre daquele ano, liguei para a psicopedagoga, contei-lhe da disponibilidade de Caio para aprender e seguir 
instruções e disse que acreditava que naquele momento seria possível realizar o trabalho com ela. Já havia apontado essa possibilidade para os pais, que o levaram novamente ao consultório e o trabalho se iniciou. Não tínhamos dúvidas de que Caio estava pronto para enfrentar os novos desafios na $1^{a}$ série, os avanços haviam sido enormes, apesar dos momentos de angústia e sofrimento que pareciam que nunca terminariam. Caio se abrira para aprender com o outro de forma explícita: tornara-se aluno.

\section{O fim de um ciclo e como seguir em frente}

No início da $1^{\text {a }}$ série, Caio manteve as idas à minha sala e iniciou o trabalho psicopedagógico, dois espaços que usava com muita sabedoria. Aprendera a pedir ajuda, a aceitar alguns encaminhamentos e queria aprender mais. Continuei mesclando atividades que vinham encaminhadas por sua professora Marina e outras que eu propunha ou que ele pedia. Pedi indicação de CDs que lidassem com alfabetização a uma amiga psicopedagoga, que me indicou a série "Arthur" (usei os da $1^{\mathrm{a}}$ e $2^{\mathrm{a}}$ série). Avançamos muito com esse recurso, pois, àquela altura, ele já usava bem o computador, e os conteúdos de Português e Matemática, que eram trabalhados nos programas, ganhavam sentido. Na Figura 7 pode-se ver um exemplo de sua escrita no início da $1^{\text {a }}$ série em que é possível distinguir vários nomes de animais escritos de forma silábico-alfabética.

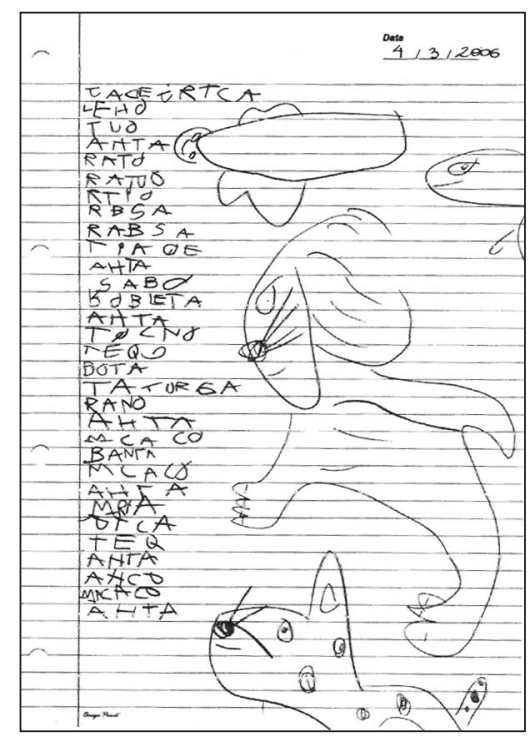

Figura 7 - Lista de animais (idade: oito anos)

No início da $1^{a}$ série, costumávamos treinar os movimentos da letra cursiva. Como Caio estava em pleno processo de 
alfabetização, não apresentamos essa possibilidade para ele, usando as aulas para que se exercitasse em sua hipótese de escrita. Não víamos necessidade de ele escrever em cursiva naquele momento, tínhamos claro que se escrevesse em qualquer tipo de letra e conseguisse ler em fontes variadas, se possível também na cursiva, estaria garantida a comunicação. Percebemos que sua letra de forma tinha, às vezes, um desenho confuso e treinamos sua caligrafia. Além disso, resolvemos trabalhar com a leitura na letra cursiva, além da letra de forma e imprensa como já vinha ocorrendo.

Conversei com minha coordenadora, sugerindo que colocássemos um computador na sala de Caio de modo a encaminhar senão todo, mas boa parte do trabalho que fazia comigo para dentro da sala com as professoras Marina e Cecília. Iniciamos o semestre com o computador em sala, com isso, foi possível passar tarefas individuais para Caio quando não se envolvia com o coletivo, embora ainda me visitasse e precisasse dar suas voltas pela escola vez por outra.

No segundo semestre, Caio finalizou sua alfabetização, com o trabalho da escola e o apoio da psicopedagoga, que continuava a nos contar do bom aproveitamento que fazia do trabalho desenvolvido por ela. Depois que se alfabetizou, passou a escrever muito; textos longos, cheios de palavras. Escrevia até o fim da página, usando inclusive a margem inferior da folha. Escrevia rapidamente, sem se ater ao que era pedido, como se fosse uma descarga de energia, de alguma forma parecida a quando desenhava um desenho atrás do outro. Nos desenhos, começaram a aparecer os nomes dos personagens e heróis escritos com letras diferentes como na Figura 8:

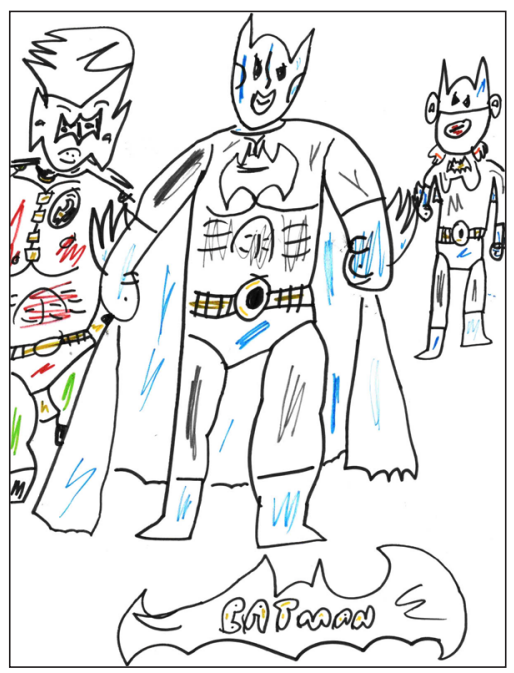

Figura 8 - Batman e Robin (idade: oito anos e seis meses) 
Nessa época, assistiu a vários filmes que tinham os superheróis como tema, o que se somou a seu repertório. Costumava me contar de detalhes marcantes dizendo que o filme "Batman begins", por exemplo, era muito escuro e que ele teve medo; "não gostei" afirmou. Perguntava se eu também assistira a determinado filme de seu interesse e comentava "Ah, precisa assistir, Gáu!" Confesso que assisti a alguns deles, só para alimentar nossa conversa.

Os heróis apareciam em muitas das listas que escrevia. Impressionou-me o fato de ele escrever com ortografia quase perfeita, usando sílabas complexas e acentos ou tentando usá-los desde que se alfabetizou. Segue uma das listas que produziu nessa época. Devido aos nomes dos heróis há várias palavras em "inglês" (Figura 9):

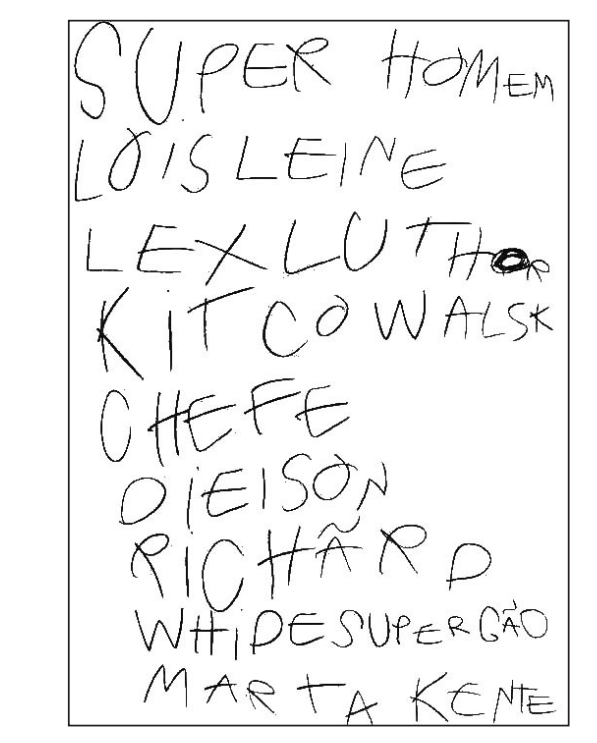

Figura 9 - Lista de heróis (idade: oito anos e seis meses)

No segundo semestre, viajamos com o grupo todo (140 crianças) para um acantonamento de três dias. Combinei com os pais que, se Caio não aguentasse, telefonaria para eles irem buscá-lo e pedi dicas de cuidados básicos. Marina e o professor de Educação Física ficaram no quarto com o grupo em que ele estava e se revezaram nos cuidados. Caio levou um boneco do Super-homem que ele colocava para dormir, tomar banho etc. À noite, se cansava mais cedo que os demais e ficava irritado. Quando percebíamos sua irritação, o professor de Educação Física o levava para o quarto e ele se preparava para dormir com seu boneco. Quando os outros alunos chegavam para dormir, já estava acomodado ou dormindo. Caio participou dos passeios e das atividades propostas nos três dias de viagem, divertindo-se ao lado dos colegas, vencendo mais um desafio! 
$\mathrm{Na}$ volta do acantonamento, propus como atividade, que ele escrevesse o que vivenciou por lá. Utilizei uma foto do lugar para desencadear a escrita. 0 texto foi criado e digitado por ele a partir de algumas perguntas que lhe fiz:

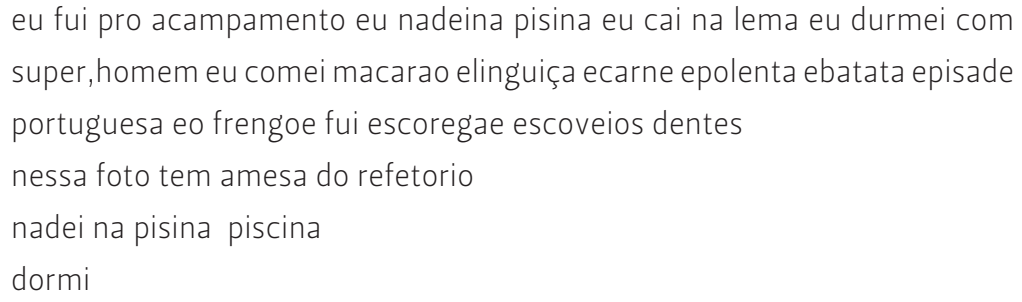

Muitas conversas em diferentes instâncias foram necessárias para pensarmos no ano seguinte. Como sempre, tínhamos dúvida do que seria melhor para Caio naquele momento, ficar ou seguir em frente. A primeira conversa se deu entre minha coordenadora e a coordenadora do Ensino Fundamental. Nesse encontro, minha coordenadora apontou características da turma e focou a conversa em alguns alunos que requereriam especial atenção. Falou sobre as características de Caio, seus saberes, suas dificuldades. Além das conversas frequentes com os pais, marquei com a psicopedagoga, e, em seguida, com a psicanalista. A ideia foi de ouvir todos os envolvidos no acompanhamento de Caio e somar estas visões às de Marina e da auxiliar da classe. Eram claros para todos nós os avanços de Caio dentro de seu modo de ser. Após todas essas conversas e retomando inúmeras vezes o tema com Marina e sua parceira de sala, decidimos apostar na ida dele para a $2^{\text {a }}$ série. Marcamos um último contato com os pais para falarmos dessa nova etapa.

Tínhamos programado uma visita à unidade II, onde os alunos estudariam a partir da $2^{a}$ série. Conversei com Marina considerando levar Caio ao local mais de uma vez para que pudesse se ambientar melhor, o que ela encampou imediatamente. Quando fez a visita pela primeira vez, junto com seu grupo de classe, Caio não conseguiu ficar o tempo todo com os colegas, gritando muito. Tornou a ir individualmente, uma vez acompanhado por Marina e outra por mim e, nessas visitas, ganhou intimidade com o espaço e iniciou um bom contato com a professora de biblioteca.

Uma das atividades propostas como finalização da $1^{\text {a }}$ série era fazer uma pintura na parede do pátio. Desenhar e pintar não eram desafios para Caio, mas seguir o planejamento do grupo, incluindo um tema único e um esboço coletivo do que seria pintado, exigiria muito dele. Não poderia pintar o que quisesse, onde quisesse. 0 tema da classe foi uma das paisagens brasileiras que haviam 
estudado e que Caio conhecia muito bem: o Pantanal. Fez o esboço do jacaré que desenharia, afastou-se com a auxiliar e, então, voltou ao muro para pintá-lo, respeitando o restante da paisagem já desenhada pelo grupo, mostrando mais uma vez a possibilidade de inserir-se, a seu modo, no grupo. Chegáramos ao final do ciclo, Caio estava pronto para sair debaixo de nossas asas, tal qual seus colegas. No ano seguinte, seguiria para a $2^{a}$ série, na nova unidade.

Os caminhos da inclusão não são lineares, como não foi o percurso de Caio, no entanto "a inclusão escolar tem se mostrado essencial para que as crianças e os adolescentes com TGD [transtorno global de desenvolvimento] desenvolvam competências a serem utilizadas no decorrer de toda a sua vida. [...] é fundamental que seja garantido à criança o direito à escola desde a Educação Infantil" (Brasil, 2010, p. 41).

Acompanhar o percurso de Caio fez de mim uma educadora mais competente e uma pessoa melhor. Acredito que isso ocorreu com muitos dos que conviveram com ele, inclusive seus colegas. 0 trabalho com as diferenças do ser humano ainda é um desafio para as instituições escolares, que carregam a história da busca da homogeneização dos alunos, do planejamento único, da falta de flexibilização, da avaliação como forma de excluir e não de apontar novos caminhos para a aprendizagem; creio que cada história de atendimento à diversidade é um pequeno grão que pode nos ajudar a fortalecer o paradigma da escola inclusiva. Encerro este texto com as palavras de Sekkel (2003, p. 7-8):

Escolher é tomar decisões, e cada escolha feita define caminhos, desvenda horizontes, e traz consigo perdas e ganhos. No exercício das escolhas, das decisões que assumimos, construímos a nossa própria identidade, e chegamos ao outro. Pensando assim, viver é saber perder e ganhar, é poder correr riscos. A reflexão e a confiança são os poderes de que dispomos para orientar nossas escolhas. 


\section{REFERÊNCIAS}

BRASIL. Ministério da Educação. A Educação Especial na perspectiva da inclusão escolar: transtornos globais do desenvolvimento. Brasília: MEC/Secretaria de Educação Especial. Universidade Federal do Ceará, 2010.

GRANDIN, Temple; SCARIANO, Margareth M. Uma menina estranha: autobiografia de uma autista. São Paulo: Cia. das Letras, 2010.

KLIN, A; ROSARIO, M. C; MERCADANTE M. T. Autismo, Síndrome de Asperger e cérebro social. In: MERCADANTE, M. T; ROSARIO, M. C. Autismo e Cérebro Social. Segmento Farma, São Paulo, 2009.

MANTOAN, Maria Teresa Eglér. Inclusão escolar: caminhos, descaminhos, desafios, perspectivas. In: MANTOAN, Maria Teresa Eglér. O desafio das diferenças nas escolas. Petrópolis, RJ: Vozes, 2009.

SACKS, Oliver. Um antropólogo em Marte: sete histórias paradoxais. São Paulo: Cia. das Letras, Companhia de bolso, 2009

SAAD, Suad Nader. Um estudo exploratório de fatores intervenientes no desenvolvimento de pessoas com síndrome de Down. In: SAAD, Suad Nader. Preparando o caminho da inclusão: dissolvendo mitos e preconceitos em relação à pessoa com síndrome de Down. São Paulo: Vetor, 2003.

SEKKEL, Marie Claire. A construção de um ambiente inclusivo na educação infantil: relato e reflexão sobre uma experiência. Tese (Doutorado em Psicologia) Instituto de Psicologia, Universidade de São Paulo, São Paulo, 2003.

Recebido em fevereiro de 2012 Aprovado em março de 2012

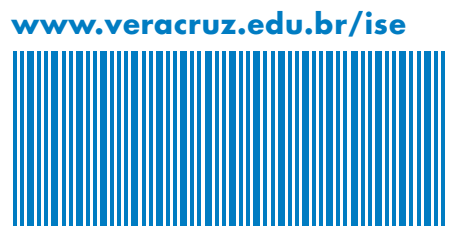

